\title{
Identifying the effects of land use changes and check dams on sediment yield in a watershed of the Loess Plateau, China
}

\author{
Xiang Zhang ${ }^{1}$, Dongli $\mathrm{She}^{2}$, Xuan Huang ${ }^{2}$, and Guangbo Wang ${ }^{2}$ \\ ${ }^{1}$ State Key Laboratory of Soil Erosion and Dryland Farming on the Loess Plateau \\ ${ }^{2}$ Key Laboratory of Efficient Irrigation-Drainage and Agricultural Soil-Water Environment \\ in Southern China, Ministry of Education
}

August 17, 2020

\begin{abstract}
Reforestation and check dam construction have been progressively implemented on the Loess Plateau for several decades. However, it is still unclear how the two major sediment control strategies affect soil erosion and sediment yield in a large watershed. A combination of field investigation and model simulation was employed to quantitatively identify the impacts of the two measures on soil erosion and sediment yield in the Kuye River watershed. Significant land use changes, with the conversion of arable land and bare land to vegetation cover and construction land, occurred in the study watershed from 1987 to 2016. In addition, 306 key dams were built in the watershed, with a total storage capacity of $316.64 \mathrm{Mm} 3$, according to the statistical data of 2011. Hot spot analysis showed that the high-risk regions for soil erosion and sediment yield were mainly concentrated on the periphery of Shenmu County and the outlet of the watershed. The simulation results showed that the land use changes from 1987 to 2016 remarkably reduced sediment yield by $51.14 \%$ without considering the action of check dams. In the 1987 scenario, the sediment yield was reduced by $50.44 \%$ when considering the action of check dams compared with the yield that was estimated without consideration of check dams. Under the combined effect of the two factors, the sediment yield decreased by $73.91 \%$ in 2016 . More attention should be paid to check dams, and corresponding measures should be taken to protect them, especially in the flood period.
\end{abstract}

\begin{abstract}
Reforestation and check dam construction have been progressively implemented on the Loess Plateau for several decades. However, it is still unclear how the two major sediment control strategies affect soil erosion and sediment yield in a large watershed. A combination of field investigation and model simulation was employed to quantitatively identify the impacts of the two measures on soil erosion and sediment yield in the Kuye River watershed. Significant land use changes, with the conversion of arable land and bare land to vegetation cover and construction land, occurred in the study watershed from 1987 to 2016. In addition, 306 key dams were built in the watershed, with a total storage capacity of $316.64 \mathrm{Mm}^{3}$, according to the statistical data of 2011. Hot spot analysis showed that the high-risk regions for soil erosion and sediment yield were mainly concentrated on the periphery of Shenmu County and the outlet of the watershed. The simulation results showed that the land use changes from 1987 to 2016 remarkably reduced sediment yield by $51.14 \%$ without considering the action of check dams. In the 1987 scenario, the sediment yield was reduced by $50.44 \%$ when considering the action of check dams compared with the yield that was estimated without consideration of check dams. Under the combined effect of the two factors, the sediment yield decreased by $73.91 \%$ in 2016 . More attention should be paid to check dams, and corresponding measures should be taken to protect them, especially in the flood period. The results can serve as a reference for watershed management and policy implementation.
\end{abstract}

Keywords : Check dam; Soil erosion; Sediment yield; SEDD model; Kuye River watershed 


\section{INTRODUCTION}

Soil erosion is wide-ranging worldwide and has irreversible effects on all-natural and artificial ecosystems (Fu et al., 2011). It is not only the primary cause of soil deterioration (Marques et al., 2008), land productivity decline (Lantican et al., 2003), and degradation of rivers, lakes and estuaries but also often carries sediments and pollutants. Soil erosion has accelerated approximately $85 \%$ of global land degradation and resulted in a $17 \%$ reduction in food production (Tang et al., 2015), which has become one of the most serious societal and environmental problems in the world.

The middle and upper reaches of the Yellow River basin are located on the Loess Plateau of China. Owing to its unique soil characteristics, climate conditions and extremely fragile ecosystem (Wang et al., 2017; Xin et al., 2012), the Loess Plateau is a global hot spots of soil erosion. Approximately $40 \%$ of the whole Loess Plateau suffers from extremely high erosion, and the annual soil erosion modulus is more than $5000 \mathrm{t} / \mathrm{km}^{2}$ (Fu et al., 2011), which increases the risk of soil degradation and restricts the sustainable development of the ecosystem (Zhao et al., 2016). The high-risk areas are mainly concentrated in hilly and gully loess areas (Chen et al., 2007), which are the main source of Yellow River sediment. Since the 1950s, to control severe soil erosion, the government has issued many policies and implemented a series of soil conservation measures for the Loess Plateau. The control of soil and water loss on the Loess Plateau can be divided into two parts, namely, slope vegetation restoration (i.e., reforestation) and gully control (i.e., check dams).

As a main measure for reducing erosion, vegetation restoration has been widely used on the Loess Plateau, especially since the implementation of the 'Grain for Green' project. The increase in vegetation coverage can effectively control soil erosion through root consolidation of soil, increased infiltration, and reduced surface runoff and water flow velocity (Bruijnzeel, 2004), improving the resistance of the soil erosion and reducing water erosion capacity and sediment transport capacity (Rey et al., 2005; Vanacker et al., 2007). At the same time, the variation in vegetation cover will directly lead to changes in land use. In fact, land use changes will be affected by human activities, such as the implementation of policies and urban development and its impact on soil erosion is bidirectional. Changes in land use may not only lead to sediment reduction (Choukri et al., 2020) but also increase soil erosion and further lead to land degradation (Aneseyee et al., 2020). For example, Quiñonero-Rubio et al. (2016) used the WaTEM/SEDEM model to simulate the Upper Taibilla catchment of Spain and indicated that afforestation reduced sediment yield by $13.9 \%$ (1956-2000). Aneseyee et al. (2020) demonstrated that land use changes increased soil loss by $26.25 \%$ and sediment export by $3.45 \%$ (1988-2018), mainly due to the expansion of urbanization and reclamation.

The construction of check dams has become an effective soil and water conservation measure for sediment control. A large number of check dams have been constructed in the gully channel to intercept the sediment, block floods, and reduce downstream scouring (Ran et al., 2008). When the check dams are fully filled, the main component of the land behind check dams is surface soil that is rich in nutrients, and its fertility is much higher than that of sloped farmland. According to reports, approximately $3200 \mathrm{~km}^{2}$ of dam croplands were formed in 2002 (Jin et al., 2012). Moreover, check dams effectively prevent sediment from entering the Yellow River, thus reducing the sediment concentration of the Yellow River (Ran et al., 2008). Although not widely used worldwide, check dams have been applied to control soil erosion and have been reported in France, the United States, Spain, China and elsewhere (Abedini et al., 2012; Bellin et al., 2011; Borja et al., 2018; Castillo et al., 2007; Fang, 2017). Polyakov et al. (2014) carried out field sampling in the Santa Rita Experimental Range in the United States and found that the check dams retained 50\% of sediment yield. By measuring the sediment deposition within the gully channels of the Loreto catchment in the Andean Mountains, Borja et al. (2018) indicated that check dams reduced the sediment exported by more than 70\%. Boix-Fayos et al. (2008) applied the WATEM-SEDEM model to the Rogativa catchment of Spain and showed that check dams reduced the sediment load by approximately $77 \%$ without land use changes. Xu et al. (2013) explored the interception benefit of check dams in the Yanhe River watershed and revealed that the proportional reduction in sediment reached from 34.6-48.0\% in the rainy season (1984-1987) and increased to between 79.4 and $85.5 \%$ from 2006-2008.

Currently, over the past six decades, the sediment concentration of the Yellow River has decreased substan- 
tially (Wu et al., 2020), and the main tributaries in the middle reaches of the Yellow River have reported that sediment load has decreased rapidly (Gao et al., 2017; Rustomji et al., 2008; Yue et al., 2014). Hence, it is particularly important to understand the driving factors and mechanisms behind the changes in sediment load, which is also a prerequisite for sustainable watershed management (Montgomery, 2007). In addition, as the main influencing factor of sediment reduction, the vegetation coverage of the Loess Plateau has improved in recent decades (Li et al., 2017; Zhao et al., 2017), and the number of check dams has reached 110,000 (Jin et al., 2012). After years of implementation of soil and water conservation measures, the contribution rates of vegetation restoration and check dam construction to reductions in soil erosion and sediment yield in this area remain unclear.

To quantitatively identify the impact of land use changes and check dams, the Kuye River watershed, with an area of $8651 \mathrm{~km}^{2}$ on the Loess Plateau, was selected as the study area by combining field investigations with model simulation. The main objectives of this study were to (1) explore the characteristics of soil erosion and sediment yield under the conditions of land use changes and check dams and to (2) quantify the contribution of check dam construction and man-made land use changes to sediment load reduction in the Kuye River watershed, which is a typical watershed in the coarse sandy hilly catchment region of the Yellow River basin.

\section{MATERIALS AND METHODS}

\subsection{Description of study area}

The Kuye River (Fig. 1 ) is a first-order tributary of the middle Yellow River, which flows through Inner Mongolia and Shaanxi and finally flows into the Yellow River. The area of the Kuye River watershed $\left(38^{\circ} 22^{\prime}-\right.$ $39 \operatorname{deg} 50^{\prime} \mathrm{N}, 109 \mathrm{deg} 28^{\prime}-110 \mathrm{deg} 45^{\prime} \mathrm{E}$ ) is $8651 \mathrm{~km}^{2}$, with a mainstream length of $242 \mathrm{~km}$ and an average channel slope of 2.6 The elevation ranges from $713 \mathrm{~m}$ in the southeast to $1575 \mathrm{~m}$ in the northwest. There are two main tributaries (Wu-lan-mu-lun and Bei-niuchuan) in the upper reach of the watershed, and the Wenjiachuan hydrometrical station is located at the outlet of the Kuye River. The watershed has a typical arid to semiarid continental climate, with a multiyear average precipitation and temperature of $415 \mathrm{~mm}$ and $7.9 \mathrm{degC}$, respectively. The average annual evaporation is $1788 \mathrm{~mm}$. Intense storms mainly take place in July and August, accounting for more than $52 \%$ of the annual rainfall. Therefore, local short-term floods often occur in the watershed during this period. According to the measured data of the Wenjiachuan hydrological station, the sediment load in July and August accounts for $90 \%$ of the annual total (Cai et al., 2019).

Due to the sparse vegetation cover, loose soil, terrain fragmentation and dense gullies in this watershed, it has become one of the main sources of sediment in the Yellow River. The average annual sediment load measured at the Wenjiachuan hydrological station from 1954 to 2000 was $1.00 \times 10^{8}$ t $\left(10800 \mathrm{t} / \mathrm{km}^{2} / \mathrm{a}\right)$ (Rustomji et al., 2008). However, the observed sediment load decreased significantly over the past six decades. Compared with the 1960-1999 period, the average annual runoff and sediment discharge from 2000-2016 decreased by $76.72 \%$ and $94.50 \%$, respectively (Zhao et al., 2019).

\subsection{Datasets}

The daily precipitation records of 50 rainfall stations and the daily sediment concentration data of the Wenjiachuan gauge in 1987 and from 2006-2016 were obtained from the "Hydrological Yearbook of the People's Republic of China - Hydrological Data of the Yellow River Basin".

The digital elevation map (DEM) came from the Geospatial Data Cloud, with a spatial resolution of 30 m (www.gscloud.cn). The DEM of the Kuye River watershed was extracted with the hydrological analysis tool in ArcGIS 10.2 (ESRI), and the slope length and slope factor for the RUSLE model were primarily calculated with the DEM.

The land use scenarios for 1987 and 2006 were derived from the Landsat 5 Thematic Mapper (TM) remote sensing images downloaded from the United States Geological Survey (USGS) (https://glovis.usgs.gov/), while those for 2016 were from the Geospatial Data Cloud website (www.gscloud.cn). Then, a hybrid land use classification technique, which involved unsupervised classification and visual interpretation, was used. Unsupervised classifications were carried out using the iterative self-organizing data analysis (ISODATA) 
clustering algorithm, while visual interpretation was mainly employed using Google Earth's historical orthophoto images of corresponding years. To ensure the quality and accuracy of the data, field investigations and in-depth consultations with local elders were undertaken. Seven land use types were identified: forests, grassland, shrubland, bare land, arable land, water bodies and urban and mining areas.

\subsection{Model description}

The sediment delivery distributed (SEDD) model has been extensively used in different regions of the world. Based on the concept of the revised universal soil loss equation (RUSLE) model, GIS techniques were integrated to predict the sediment delivery ratio (SDR) at the morphological unit and catchment scale and then to predict the spatial pattern of annual soil erosion and sediment yield. The SEDD (Ferro and Minacapilli, 1995) model estimates the sediment yield at the catchment outlet according to the following formula:

$\mathrm{SY}_{i}=\mathrm{SE}_{i} \bullet \mathrm{SDR}_{i}=R_{i} \bullet K_{i} \bullet \mathrm{LS}_{i} \bullet C_{i} \bullet P_{i} \bullet \mathrm{SDR}_{i}(1)$

where $S E_{i}$ is the average of annual soil erosion (t/ha/a) on pixel $i ; S D R_{i}$ is the sediment delivery ratio for pixel $i ; R_{i}$ refers to the rainfall-runoff erosivity factor $\left(\mathrm{MJ}^{*} \mathrm{~mm} / \mathrm{ha}{ }^{*} \mathrm{~h}\right) ; K_{i}$ denotes the soil erodibility factor (t*ha*h/MJ*ha*mm); $L S_{i}$ expresses the topographic factor; $C_{i}$ signifies the cover-management factor; and $P_{i}$ shows the support practice factor.

To explain the relationship between rainfall and erosion, Wischmeier and Smith (1978) proposed the R factor to quantify the impact of rainfall and runoff on soil erosion. Since the daily rainfall data of 50 rainfall stations were available, the method proposed by Zhang et al. (2002) was used to determine the rainfall erosivity factor, which was mainly assessed with the daily rainfall data using a half-month rainfall erosivity model. The average annual $\mathrm{R}$ factor was generated by kriging interpolation using data from 50 rainfall stations, and the raster of the $\mathrm{R}$ factor in 2006 is shown in Fig. 2 a.

The soil erodibility factor was applicable to characterize the sensitivity of soil to water erosion (Rao et al., 2014). Based on the soil map (1:500,000 scale) of the Loess Plateau and the revised erosion/productivity impact calculator (EPIC) model (Williams et al., 1984), the value of the soil erodibility factor was derived (Fig. 2 b).

The LS factor is an index for measuring the impact of topography on soil erosion, and with the increase in slope length and gradient, the amount of erosion will increase. As the Kuye River watershed was located on the Loess Plateau, which has complicated terrain, the terrain factor calculation tool 2.0 developed by Fu et al. (2015) for the Loess Plateau was imposed to calculate the LS factor (Fig. 2 c). The DEM was adopted as the main data source for this calculation tool.

The cover-management factor reflects the effect of soil management on soil erosion rates, which are mainly related to land use type, vegetation cover, surface roughness and soil moisture (Renard et al., 1997). In this paper, the method proposed by Cai et al. (2000) was used to evaluate the C factor by integrating the normalized vegetation index (NDVI), which was obtained from remote sensing images of different periods of the Kuye River watershed (Fig. 2 d).

The $\mathrm{P}$ factor represents the influence of supporting measures on sediment control and is generally assigned according to previous research results combined with land use types (Zhou et al., 2019). However, due to the large scale of the Kuye River watershed, other soil and water conservation activities were relatively limited compared with throughout the whole watershed, and the dams played a leading role in sediment control (Ran et al., 2008). To quantitatively analyze the influence of the check dam on sediment load, the trapping efficiencies of the dams (Fig. 4 c) were applied to evaluate the P factors. For a detailed method for calculating the P factor, please refer to Zhao et al. (2017).

According to Ferro and Porto (2000), the SDR value of each grid cell is calculated as follows:

$\mathrm{SDR}_{i}=\exp \left(-\beta \bullet t_{i}\right)=\exp \left(-\beta \bullet \frac{l_{i}}{k_{i} \sqrt{s_{i}}}\right)(2)$ 
where $\beta$ is a coefficient that is affected by the roughness distribution along the flow path and is related to time. $t_{i}$ is the travel time from cell $i$ to the nearest stream reach, and $l_{i}$ is the flow length $(\mathrm{m}) . k_{i}$ is a coefficient dependent on surface roughness characteristics $(\mathrm{m} / \mathrm{s})$, and $s_{i}$ represents the slope of the cell. The determination of the $\beta$ value followed the method of $\mathrm{Fu}$ et al. (2006). To ensure the proper use of formula (2), the minimum value of $s_{i}$ was set as 0.003 (Fernandez et al., 2003; Fu et al., 2006). The value of $k_{i}$ was extracted from previous studies (Fernandez et al., 2003; Gashaw et al., 2019).

To calibrate the model, in 2018, we selected two small check dams without a sluicing gate in the Kuye River watershed, and the sediment produced by soil erosion in the dam-controlled watershed was completely intercepted by the dams. For details of these two check dams, please refer to Zhang et al. (2020). Trench excavation was carried out on the dam land and divided the flood couplets to obtain the annual erosion modulus of the two dam-controlled watersheds from 2007 to 2018 (Wang, 2020). The area-weighted average of the annual erosion modulus of the two dam-controlled watersheds was used as the annual erosion modulus for the whole Kuye River watershed from 2007 to 2018. However, it was very difficult to calibrate a model of such a large-scale watershed because the land use and the number of check dams changed continuously during the study period. To obtain a more realistic calculation, the sediment load was calculated for 1987 without considering the effect of check dams because the number of check dams and the total storage capacity were very limited (Fig. 4 ). The calculation of the annual erosion modulus and sediment load from 2006 to 2010 was based on the land use scenario in 2006 and included the effects of the check dams. The same method was applied from 2011-2016, except that the land use scenario was based on 2016. The annual erosion modulus measured from 2007-2016 was used to calibrate the model. Additionally, the SEDD model simulation results were validated by using the observed sediment load of Wenjiachuan station in 1987 and from 2006-2016.

After calibration and verification of the model, we set up six scenarios: three different land use scenarios were selected, and the role of check dams was considered or excluded for each. Based on the model factors and SDR of the corresponding years, the contribution of land use changes and check dams to soil erosion and sediment yield reduction was evaluated.

\section{RESULTS}

\subsection{Land use changes}

Fig. 3 shows that there were dramatic changes in land use, with the main conversion of arable land and bare land to grassland, shrubland, forestland and construction land. The proportion of vegetation coverage increased from $60 \%$ in 1987 to $86 \%$ in 2016 . In addition, the urban and mining areas expanded rapidly from $9.62 \mathrm{~km}^{2}$ in 1987 to $437.23 \mathrm{~km}^{2}$ in 2016 (Table 1 ). This was mainly reflected in the urban expansion of Shenmu County, Dongsheng district and Yijinhuoqi County, as well as in the development of coal mines, which showed that the population, economy and urbanization had grown rapidly in the past three decades. In contrast, after decades of implementation and promotion of the abandonment of grazing and 'Grain for Green' policies, the area of arable land and bare land in the study presented a gradually decreasing trend. The area of arable land decreased from $2182.62 \mathrm{~km}^{2}$ in 1987 to $533.71 \mathrm{~km}^{2}$ in 2016 . The proportion of bare land decreased from $13.43 \%$ in 1987 to $0.75 \%$ in 2016 , and the area decreased by $1097.24 \mathrm{~km}^{2}$.

\subsection{Check dam construction}

Fig. 4 shows the spatiotemporal distribution, filled ratio and trapping efficiencies of the check dams. Based on the general survey data of water conservation of the Yellow River Conservancy Committee, there were 306 key dams in the Kuye River watershed, with a total storage capacity of $316.64 \mathrm{Mm}^{3}$ until 2011. In 1987, only 32 check dams had been built, with a total control area of $108.2 \mathrm{~km}^{2}$ and total storage of 35.20 $\mathrm{Mm}^{3}$. The number, control area and storage capacity of check dams only accounted for approximately $10 \%$ of the total amount, and most of them were located in the mid-lower reaches of the watershed (Fig. 4 a). By 2003, 143 check dams had been built in the watershed, with a total storage capacity of $138.24 \mathrm{Mm}^{3}$. After 2003, the construction of check dams was further strengthened, mainly due to the 'Hydraulic highlight project' launched by the Ministry of Water Resources of China. The high fill ratio of check dams was mainly concentrated in the lower reaches of the watershed (Fig. 4 b). According to data statistics, these dams were 
mainly built before 1987, and the fill ratio of 19 dams exceeded $75 \%$. In contrast, there were 233 check dams with low fill ratios upstream and downstream of the watershed, which can also reflect that the check dams in the watershed still had enough storage capacity to intercept sediment.

\subsection{Model calibration and validation}

Fig. 5 a shows the model calibration using the annual erosion modulus, which was obtained through field excavation in 2018 (Wang, 2020). The annual erosion modulus ranged from 39.88 to $64.02 \mathrm{t} / \mathrm{ha} / \mathrm{a}$, with an average value of $50.83 \mathrm{t} / \mathrm{ha} / \mathrm{a}$. Correspondingly, the simulated soil erosion modulus changed from 40.99 to $58.70 \mathrm{t} / \mathrm{ha} / \mathrm{a}$, with an average value of $49.48 \mathrm{t} / \mathrm{ha} / \mathrm{a}$. The $\mathrm{R}^{2}$ reached 0.83 , which indicated that the results of the model were, overall, in good agreement with the actual measured values.

Fig. 5 b shows the relationship between the measured and simulated annual sediment loads at Wenjiachuan station. The annual sediment loads in 1987 and from 2006-2016 were mainly simulated for model validation. The measured sediment load at Wenjiachuan station varied from 0.05 Mt in 2016 to $33.97 \mathrm{Mt}$ in 1987, while the simulated annual average sediment load ranged from $8.55 \mathrm{Mt}$ to $32.77 \mathrm{Mt}$. According to the fitting results of the scatter diagram $\left(\mathrm{R}^{2}>0.90\right)$, the simulation results of the model were basically consistent with the measured values, but compared with the measured values in recent years, the model tended to overestimate the sediment load.

\subsection{Characteristics of soil erosion and sediment yield}

Table 2 shows the classification of soil erosion and sediment yield under three different land use scenarios. According to the Chinese Soil Erosion Classification and Grading Standards (SL190-2007), the soil erosion grade changed from micro erosion to severe erosion. In 1987, the areas of micro, mild, moderate, intensive, extreme, and severe erosion accounted for $29.61 \%, 11.56 \%, 12.83 \%, 9.64 \%, 12.45 \%$ and $23.91 \%$, respectively, of the area affected by erosion. The proportion of micro, mild, moderate, intensive, extreme, and severe erosion in 2016 was $59.68 \%, 11.38 \%, 8.80 \%, 5.44 \%, 6.08 \%$ and $8.61 \%$, respectively. The area affected by mild or less serious erosion accounted for more than $70 \%$ of the whole watershed, which indicated that the soil erosion in the watershed had been well controlled by 2016. In 1987, the area of high erosion rates (>intensive) was $3981.29 \mathrm{~km}^{2}$, accounting for $46 \%$ of the whole watershed area. In 2016, the area of high erosion rates was $1739.63 \mathrm{~km}^{2}$, accounting for $20.14 \%$ of the whole watershed area. Nevertheless, compared with in 1987 , the area with high erosion rates decreased by $2241.66 \mathrm{~km}^{2}$ in 2016 , and the area with severe erosion shrank by $1325.42 \mathrm{~km}^{2}$. The results showed that land use changes and check dams played a remarkable role in reducing erosion.

The sediment yield was artificially divided into three grades: low, moderate and high sediment yield (Table 2 ). The distribution area of sediment yield under the three land use scenarios was low $>$ moderate $>$ high. Moreover, over time, the area occupied by the low sediment yield rate increased (from 4957.94 to 7276.03 $\mathrm{km}^{2}$ ), while the others decreased. This indicated that sediment control in 2016 greatly improved under the influence of land use changes and check dams.

Considering the check dams, we applied hot spot analysis (Getis-Ord Gi*) in ArcGIS software to analyze the soil erosion and sediment yield of the Kuye River watershed in 1987 and 2016 (Fig. 6 ). The distribution of cold and hot spots of soil erosion in 1987 and 2016 was consistent with that of sediment yield, and we found that the hot spots of soil erosion and sediment yield were mainly clustered around Shenmu County (Fig. 1 ) and the downstream export area of the watershed. This indicated that the high-risk regions of soil erosion and sediment yield were mainly concentrated on the periphery of Shenmu County and at the exit of the watershed. However, the hot spot region in 2016 decreased compared with that in 1987. On the other hand, most of the cold spots were identified in Yijinhuoqi County, especially in 2016. This signified that the erosion degree in this area was relatively low.

3.5 The influence of land use changes and check dams on soil erosion and sediment yield

Under different land use scenarios, the results of soil erosion and sediment yield simulated by the model from 1987 to 2016 showed a decreasing trend (Table 3 ). Compared with 1987, the total amount of soil erosion 
in 2006 decreased by $16.68 \%$. For the 2016 land use scenario, a $25.37 \%$ decrease in total soil erosion was discovered with respect to 1987 , mainly due to the increase in vegetation coverage by $26.31 \%$, the decrease in arable land by $19.06 \%$, and the decrease in bare land by $12.70 \%$ (Table 1 ). For the scenario considering land use changes and check dams, soil erosion decreased by $50.55 \%$ in 1987, 57.41\% in 2006 and $60.07 \%$ in 2016. This circumstance was related to the benefits of a great quantity of soil being consolidated by plants and eroded soil being intercepted by check dams.

The average SDR values in 1987, 2006 and 2016 were $0.32,0.28$ and 0.23 , respectively, across the whole watershed (Table 3 ), showing a decreasing trend. The results expounded that with the implementation of the 'Grain for Green' policy, land use changes affected the variation in the sediment transport rate.

Without considering the influence of check dams, the annual sediment yield in 2006 decreased by $30.33 \%$ compared with that in 1987, and the corresponding reduction in soil erosion was $16.68 \%$, which indicated that land use changes reduced the values of SDR (as mentioned above) and further increased the impact on sediment yield in the watershed. The reduction in sediment yield under the land use scenario in 2016 reached $51.14 \%$. When the influence of land use changes and check dams was considered, the sediment yield decreased by $50.44 \%$ in 1987 and by $65.61 \%$ in 2006 . Under the joint action of check dams and afforestation, the contribution rate of sediment yield reduction reached a maximum of $73.91 \%$ in 2016 .

\section{DISCUSSION}

\subsection{Causes of soil erosion and sediment load reduction}

It has been confirmed that the sediment load of the Kuye River has been substantially reduced over the past 60 years (Gao et al., 2017; Zhao et al., 2019). By using the model to simulate six different scenarios, we separately estimated the impact of land use changes and check dams on soil erosion and sediment load and ascertained the common effects of the two. To further ascertain the primary factors leading to soil erosion and sediment yield reduction, we analyzed the contributions of different land use types to soil erosion and sediment yield (Fig. 7 ). Without considering the effects of check dams, the amount of soil erosion in 1987 was mainly contributed by grassland, arable land and bare land, accounting for $40.90 \%, 26.09 \%$ and $13.04 \%$ of the total erosion, respectively. As of 2016, due to the increasing grassland area (Table 1 ), the amount of soil erosion caused by grassland only decreased slightly, and this land use type became the main source of soil erosion. In addition, as the area of arable land and bare land decreased rapidly, the contributions of these two land use types to soil erosion were significantly reduced by $22.60 \mathrm{Mt}$ and $12.83 \mathrm{Mt}$, respectively. Therefore, without considering the roles of check dams, the reduction in soil erosion was mainly due to the change in the land use pattern, especially the conversion from arable land and bare land to vegetation land. Considering the action of check dams, the erosion amounts from grassland, arable land and bare land decreased by $52.77 \%, 57.12 \%$ and $42.92 \%$, respectively, which were the main sources of soil erosion in 1987 . Under the three land use scenarios, the construction of check dams reduced the erosion of all land use types to varying degrees, and grassland had the largest erosion reduction.

In terms of sediment load, without considering the effect of check dams, the main sources of sediment in 1987 were arable land and bare land, accounting for $67.17 \%$ of the total sediment load. Nevertheless, grassland was no longer a major sediment source, indicating low sediment connectivity in the area. This development further led to less sediment that could be transported to the watershed outlet. Compared with in 1987, the sediment contribution of arable land and bare land decreased significantly in 2016, with a reduction of more than $85 \%$. Although the sediment loads of all land use types decreased to different degrees under the condition of check dams, the conversion of land use played a more important role in the reduction in sediment load over time. This was consistent with the results obtained in Table 3 . In summary, the significant reduction in soil erosion and sediment load in the watershed was mainly due to the conversions of arable land and bare land into forestland, grassland and shrubland (vegetation restoration) and the interception of check dams. The mutual conversion of land use types led to the reduction in sediment, which is similar to the results of Zhou et al. (2019).

Previous studies have also confirmed that vegetation restoration and check dams are the main driving factors 
of sediment load reduction (Qiankun et al., 2019; Zhao et al., 2017). However, according to the results of the hot spot analysis, there were still some high-risk regions of soil erosion and sediment yield in this watershed, which may be mainly due to the rapid expansion of Shenmu County and the large-scale mining of coal resources in the surrounding area in recent decades. Then, these hot spot areas should become the focus for implementation of effective soil and water conservation measures to intervene with soil erosion. In addition, the model in this study overestimated the sediment load in recent years, which may be partly because only the key dams were considered but the small dams, terraces, concrete roads and other soil and water conservation measures were not considered.

\subsection{Impact of land use changes and check dams on sediment yield}

Many studies have applied various models and methods to clarify the impact of land use changes or check dams on sediment load in different regions of the world (Table 4 ). The land use of the Kuye River watershed has undergone dramatic changes in the past few decades, especially since the implementation of the Grain for Green Project in 1999. Nevertheless, land use change will significantly affects soil erosion and sediment transport (Fang, 2017). In this study, the conversion of arable land and bare land into vegetation land reduced the erosion of the source area and further decreased the sediment export by diminishing the SDR of the whole watershed. This was consistent with the results of Zhou et al., (2019). In contrast, when natural vegetation is artificially transformed into other land use types, such as cultivated land and urban land, the opposite result is obtained (Aneseyee et al., 2020; Sushanth and Bhardwaj, 2019).

As the main channel construction and important soil and water conservation engineering measures, check dams play a significant role in channeling watersheds, which can conserve water and soil, provide fertile farmland and prevent the downstream channel from scouring, reducing the downstream sediment load. Previous studies (Borja et al., 2018; Polyakov et al., 2014) have confirmed that check dams can maintain a significant proportion of the sediment load. Based on data from previous studies, Ran et al. (2008) indicated that in the Kuye River watershed, the reductions in sediment mass caused by check dams were $37.2 \%$ from 1970 to 1996. Based on the results of this study, check dams reduced sediment export by $50.44 \%$ in 1987 without any changes in land use. However, with the continued restoration of vegetation in the watershed, the contribution rate of check dam construction to sediment control may decrease slightly.

Because check dams are very effective measures for sediment control in the short term and vegetation restoration is a control measure for sediment reduction in the long term, the combination of both will play a greater role in sediment retention. The simulation results of Boix-Fayos et al. (2008) showed that under the joint action of land use changes and check dams, the total sediment interception reached from 88-98\%. Zhao et al. (2017) carried out a model simulation of the Huangfuchuan catchment and discovered that the combination of land use and check dam construction in 2006 reduced the sediment yield by approximately 80\%. Fang (2017) employed a physically distributed soil erosion model to simulate the black soil area in Northeast China and found that the synergistic effect of land use changes and check dams was significantly greater than that of a single measure. However, the vegetation coverage ratio in this study area reached more than $80 \%$ in 2016 (Table 1 ), and the contribution of vegetation cover to sediment reduction may remain stable. This implies that the impact of dams on sediment reduction will be very important in the future. On the other hand, the service life of the check dams was limited. Under extreme rainstorm conditions, check dams are prone to collapse and damage (Bai et al., 2020), releasing more sediment and producing serious disasters. In view of the existing circumstances, the operation status of check dams in the Kuye River watershed should be considered, and effective measures for protecting check dams must be taken to guarantee the maximum efficiency of sediment interception.

\section{CONCLUSIONS}

This study analyzed the impacts of land use changes and check dams on sediment load in the Kuye River watershed by applying the SEDD model. The process of land use changes showed that arable land and bare land transformed into vegetation cover and construction land from 1987 to 2016, while arable land and bare land were the main sources of sediment yield in 1987. As of 2011, 306 key dams had been built in the 
Kuye River watershed, with a total storage capacity of $316.64 \mathrm{Mm}^{3}$. According to the classification of soil erosion and sediment yield, we found that under the influence of man-made measures, high erosion areas were consistently transformed into low erosion areas. Hot spot analysis showed that the high-risk regions of soil erosion and sediment yield were mainly concentrated in the periphery of Shenmu County and the outlet of the watershed, and the hot spots decreased with time. The average value of SDR for the whole watershed showed a declining trend with increasing time. In the Kuye River watershed, land use changes have reduced sediment yield by $51.14 \%$ over the past 29 years. In 1987, the sediment yield with consideration of the action of check dams was reduced by $50.44 \%$ compared that calculated with the exclusion of check dams. Under the joint action of vegetation recovery and check dam construction, the sediment load reduction reached $73.91 \%$ in 2016 .

Because it is very difficult to continue reforestation in an area with such high erosion risk and may even be impossible due to the limitation of soil moisture, the role of check dams in sediment control will become increasingly important. Nevertheless, due to the short service life, vulnerability to breakdown and other characteristics of these structures, effective measures should be implemented to ensure the operational safety of check dams, such as spillway construction and dam reinforcement, to prevent them from being washed out by large floods.

\section{ACKNOWLEDGMENT}

This study was financially supported by the Chinese Academy of Sciences "Light of West China" Program.

\section{CONFLICT OF INTEREST}

The authors declare no potential conflict of interest.

\section{REFERENCES}

Abedini, M., Md Said, M.A., Ahmad, F., 2012. Effectiveness of check dam to control soil erosion in a tropical catchment (The Ulu Kinta Basin). Catena 97, 63-70. https://doi.org/10.1016/j.catena.2012.05.003

Aneseyee, A.B., Elias, E., Soromessa, T., Feyisa, G.L., 2020. Land use/land cover change effect on soil erosion and sediment delivery in the Winike watershed, Omo Gibe Basin, Ethiopia. Sci. Total Environ. 728, 138776. https://doi.org/10.1016/j.scitotenv.2020.138776

Bai, L., Wang, N., Jiao, J., Chen, Yixian, Tang, B., Wang, H., Chen, Yulan, Yan, X., Wang, Z., 2020. Soil erosion and sediment interception by check dams in a watershed for an extreme rainstorm on the Loess Plateau, China. Int. J. Sediment Res. 35(4), 408-416. https://doi.org/10.1016/j.ijsrc.2020.03.005

Bellin, N., Vanacker, V., van Wesemael, B., Solé-Benet, A., Bakker, M.M., 2011. Natural and anthropogenic controls on soil erosion in the internal betic Cordillera (southeast Spain). Catena 87(2), 190-200. https://doi.org/10.1016/j.catena.2011.05.022

Boix-Fayos, C., de Vente, J., Martínez-Mena, M., Barberá, G.G., Castillo, V., 2008. The impact of land use change and check-dams on catchment sediment yield. Hydrol. Process. 22(25), 4922-4935. https://doi.org/10.1002/hyp.7115

Borja, P., Molina, A., Govers, G., Vanacker, V., 2018. Check dams and afforestation reducing sediment mobilization in active gully systems in the Andean mountains. Catena 165, 42-53. https://doi.org/10.1016/j.catena.2018.01.013

Bruijnzeel, L.A., 2004. Hydrological functions of tropical forests: Not seeing the soil for the trees?, Agriculture, Ecosystems and Environment. https://doi.org/10.1016/j.agee.2004.01.015

Cai, C., Ding, S., Shi, Z., Huang, L., Zhang, G., 2000. Study of Applying USLE and Geographical Information System IDRISI to Predict Soil Erosion in Small Watershed. J. Soil Water Conserv. 14(02), 20-24 (in Chinese). https://doi.org/10.13870/j.cnki.stbcxb.2000.02.005 
Cai, J., Zhou, Z., Liu, J., Wang, H., Jia, Y., Xu, C.Y., 2019. A three-process-based distributed soil erosion model at catchment scale on the Loess Plateau of China. J. Hydrol. 578, 124005. https://doi.org/10.1016/j.jhydrol.2019.124005

Castillo, V.M., Mosch, W.M., García, C.C., Barberá, G.G., Cano, J.A.N., López-Bermúdez, F., 2007. Effectiveness and geomorphological impacts of check dams for soil erosion control in a semiarid Mediterranean catchment: El Cárcavo (Murcia, Spain). Catena 70(3), 416-427. https://doi.org/10.1016/j.catena.2006.11.009

Chen, L., Wei, W., Fu, B., Lü, Y., 2007. Soil and water conservation on the Loess Plateau in China: Review and perspective. Prog. Phys. Geogr. 31(4), 389-403. https://doi.org/10.1177/0309133307081290

Choukri, F., Raclot, D., Naimi, M., Chikhaoui, M., Nunes, J.P., Huard, F., Hérivaux, C., Sabir, M., Pépin, Y., 2020. Distinct and combined impacts of climate and land use scenarios on water availability and sediment loads for a water supply reservoir in northern Morocco. Int. Soil Water Conserv. Res. 8, 141-153. https://doi.org/10.1016/j.iswcr.2020.03.003

Fang, H., 2017. Impact of land use change and dam construction on soil erosion and sediment yield in the black soil region, Northeastern China. L. Degrad. Dev. 28(4), 1482-1492. https://doi.org/10.1002/ldr.2677

Fernandez, C., Wu, J.Q., McCool, D.K., Stöckle, C.O., 2003. Estimating water erosion and sediment yield with GIS, RUSLE, and SEDD. J. Soil Water Conserv. 58(3), 128-136.

Ferro, V., Minacapilli, M., 1995. Sediment delivery processes at basin scale. Hydrol. Sci. J. 40, 703-717. https://doi.org/10.1080/02626669509491460

Ferro, V., Porto, P., 2000. Sediment delivery distributed (SEDD) model. J. Hydrol. Eng. 5(4), 411-422. https://doi.org/10.1061/(ASCE)1084-0699(2000)5:4(411)

Fortugno, D., Boix-Fayos, C., Bombino, G., Denisi, P., Quiñonero Rubio, J.M., Tamburino, V., Zema, D.A., 2017. Adjustments in channel morphology due to land-use changes and check dam installation in mountain torrents of Calabria (southern Italy). Earth Surf. Process. Landforms 42(14), 2469-2483. https://doi.org/10.1002/esp.4197

Fu, B., Liu, Y., Lü, Y., He, C., Zeng, Y., Wu, B., 2011. Assessing the soil erosion control service of ecosystems change in the Loess Plateau of China. Ecol. Complex. 8(4), 284-293. https://doi.org/10.1016/j.ecocom.2011.07.003

Fu, G., Chen, S., McCool, D.K., 2006. Modeling the impacts of no-till practice on soil erosion and sediment yield with RUSLE, SEDD, and ArcView GIS. Soil Tillage Res. 85(1-2), 38-49. https://doi.org/10.1016/j.still.2004.11.009

Fu, S., Liu, B., Zhou, G., Sun, Z., Zhu, X., 2015. Calculation tool of topographic factors. Sci. Soil Water Conserv. 13(05), 109-114(in Chinese). https://doi.org/10.16843/j.sswc.2015.05.018

Gao, P., Deng, J., Chai, X., Mu, X., Zhao, G., Shao, H., Sun, W., 2017. Dynamic sediment discharge in the Hekou - Longmen region of Yellow River and soil and water conservation implications. Sci. Total Environ. 578, 56-66. https://doi.org/10.1016/j.scitotenv.2016.06.128

Gashaw, T., Tulu, T., Argaw, M., Worqlul, A.W., 2019. Modeling the impacts of land use-land cover changes on soil erosion and sediment yield in the Andassa watershed, upper Blue Nile basin, Ethiopia. Environ. Earth Sci. 78(24). https://doi.org/10.1007/s12665-019-8726-x

Jin, Z., Cui, B., Song, Y., Shi, W., Wang, K., Wang, Y., Liang, J., 2012. How many check dams do we need to build on the loess plateau? Environ. Sci. Technol. 46(12), 8527-8528. https://doi.org/10.1021/es302835r

Lantican, M.A., Guerra, L.C., Bhuiyan, S.I., 2003. Impacts of soil erosion in the upper Manupali watershed on irrigated lowlands in the Philippines. Paddy Water Environ. 1(1), 19-26. https://doi.org/10.1007/s10333002-0004-x 
Li, E., Mu, X., Zhao, G., Gao, P., Sun, W., 2017. Effects of check dams on runoff and sediment load in a semi-arid river basin of the Yellow River. Stoch. Environ. Res. Risk Assess. 31(7), 1791-1803. https://doi.org/10.1007/s00477-016-1333-4

Li, J., Peng, S., Li, Z., 2017. Detecting and attributing vegetation changes on China's Loess Plateau. Agric. For. Meteorol. 247, 260-270. https://doi.org/10.1016/j.agrformet.2017.08.005

Marques, M.J., Bienes, R., Pérez-Rodríguez, R., Jiménez, L., 2008. Soil degradation in Central Spain due to sheet water erosion by low-intensity rainfall events. Earth Surf. Process. Landforms 33(3), 414-423. https://doi.org/10.1002/esp.1564

Montgomery, D.R., 2007. Soil erosion and agricultural sustainability. Proc. Natl. Acad. Sci. U. S. A. 104, 13268-13272. https://doi.org/10.1073/pnas.0611508104

Polyakov, V.O., Nichols, M.H., McClaran, M.P., Nearing, M.A., 2014. Effect of check dams on runoff, sediment yield, and retention on small semiarid watersheds. J. Soil Water Conserv. 69(5), 414-421. https://doi.org/10.2489/jswc.69.5.414

Qiankun, G., Zhaowei, D., Wei, Q., Wenhong, C., Wen, L., Xiaomei, X., Zhe, Y., 2019. Changes in sediment load in a typical watershed in the tableland and gully region of the Loess Plateau, China. Catena 182, 104132. https://doi.org/10.1016/j.catena.2019.104132

Quiñonero-Rubio, J.M., Nadeu, E., Boix-Fayos, C., de Vente, J., 2016. Evaluation of the Effectiveness of Forest Restoration and Check-Dams to Reduce Catchment Sediment Yield. L. Degrad. Dev. 27(4), 10181031. https://doi.org/10.1002/ldr.2331

Ran, D.C., Luo, Q.H., Zhou, Z.H., Wang, G.Q., Zhang, X.H., 2008. Sediment retention by check dams in the Hekouzhen-Longmen Section of the Yellow River. Int. J. Sediment Res. 23(2), 159-166. https://doi.org/10.1016/S1001-6279(08)60015-3

Rao, E., Ouyang, Z., Yu, X., Xiao, Y., 2014. Spatial patterns and impacts of soil conservation service in China. Geomorphology 207, 64-70. https://doi.org/10.1016/j.geomorph.2013.10.027

Rey, F., Isselin-Nondedeu, F., Bédécarrats, A., 2005. Vegetation dynamics on sediment deposits upstream of bioengineering works in mountainous marly gullies in a Mediterranean climate (Southern Alps, France). Plant Soil 278(1-2), 149-158. https://doi.org/10.1007/s11104-005-8422-3

Romano, G., Abdelwahab, O.M.M., Gentile, F., 2018. Modeling land use changes and their impact on sediment load in a Mediterranean watershed. Catena 163, 342-353. https://doi.org/10.1016/j.catena.2017.12.039

Rustomji, P., Zhang, X.P., Hairsine, P.B., Zhang, L., Zhao, J., 2008. River sediment load and concentration responses to changes in hydrology and catchment management in the loess plateau region of china. Water Resour. Res. 45, 1-17. https://doi.org/10.1029/2007WR006656

Shi, P., Zhang, Y., Ren, Z., Yu, Y., Li, P., Gong, J., 2019. Land-use changes and check dams reducing runoff and sediment yield on the Loess Plateau of China. Sci. Total Environ. 664, 984-994. https://doi.org/10.1016/j.scitotenv.2019.01.430

Sun, P., Wu, Y., Wei, X., Sivakumar, B., Qiu, L., Mu, X., Chen, J., Gao, J., 2020. Quantifying the contributions of climate variation, land use change, and engineering measures for dramatic reduction in streamflow and sediment in a typical loess watershed, China. Ecol. Eng. 142, 105611. https://doi.org/10.1016/j.ecoleng.2019.105611

Sushanth, K., Bhardwaj, A., 2019. Assessment of landuse change impact on runoff and sediment yield of Patiala-Ki-Rao watershed in Shivalik foot-hills of northwest India. Environ. Monit. Assess. 191(12). https://doi.org/10.1007/s10661-019-7932-z

Tang, Q., Xu, Y., Bennett, S.J., Li, Y., 2015. Assessment of soil erosion using RUSLE and GIS: a case study of the Yangou watershed in the Loess Plateau, China. Environ. Earth Sci. 73(4), 1715-1724. 
https://doi.org/10.1007/s12665-014-3523-z

Vanacker, V., von Blanckenburg, F., Govers, G., Molina, A., Poesen, J., Deckers, J., Kubik, P., 2007. Restoring dense vegetation can slow mountain erosion to near natural benchmark levels. Geology 35(4), 303-306. https://doi.org/10.1130/G23109A.1

Wang, G., 2020. Erosion Characteristics and Simulation in Typical Watersheds of More Sediment and Coarse Sediment Region in the Middle Reaches of the Yellow River (Dissertation, Hohai University).

Wang, Y., Fang, N., Tong, L., Shi, Z., 2017. Source identification and budget evaluation of eroded organic carbon in an intensive agricultural catchment. Agric. Ecosyst. Environ. 247, 290-297. https://doi.org/10.1016/j.agee.2017.07.011

Williams, J.R., Jones, C.A., Dyke, P.T., 1984. A modelling approach to determining the relationship between erosion and soil productivity. Trans. - Am. Soc. Agric. Eng. https://doi.org/10.13031/2013.32748

Wischmeier, W., Smith, D., 1978. Predicting rainfall erosion losses: a guide to conservation planning, U.S. Department of Agriculture Handbook No. 537. https://doi.org/10.1029/TR039i002p00285

Wu, X., Wang, H., Bi, N., Saito, Y., Xu, J., Zhang, Y., Lu, T., Cong, S., Yang, Z., 2020. Climate and human battle for dominance over the Yellow River's sediment discharge: From the Mid-Holocene to the Anthropocene. Mar. Geol. 425, 106188. https://doi.org/10.1016/j.margeo.2020.106188

Xin, Z., Ran, L., Lu, X.X., 2012. Soil Erosion Control and Sediment Load Reduction in the Loess Plateau: Policy Perspectives. Int. J. Water Resour. Dev. 28(2), 325-341. https://doi.org/10.1080/07900627.2012.668650

Xu, Y.D., Fu, B.J., He, C.S., 2013. Assessing the hydrological effect of the check dams in the Loess Plateau, China, by model simulations. Hydrol. Earth Syst. Sci. 17(16), 2185-2193. https://doi.org/10.5194/hess-172185-2013

Yue, X., Mu, X., Zhao, G., Shao, H., Gao, P., 2014. Dynamic changes of sediment load in the middle reaches of the Yellow River basin , China and implications for eco-restoration. Ecol. Eng. 73, 64-72. https://doi.org/10.1016/j.ecoleng.2014.09.014

Zema, D.A., Bombino, G., Boix-Fayos, C., Tamburino, V., Zimbone, S.M., Fortugno, D., 2014. Evaluation and modeling of scouring and sedimentation around check dams in a Mediterranean torrent in Calabria, Italy. J. Soil Water Conserv. 69(4), 316-329. https://doi.org/10.2489/jswc.69.4.316

Zhang, W., Xie, Y., Liu, B., 2002. Rainfall erosivity estimation using daily rainfall amounts. Sci. Geogr. Sin. 22(6), 705-711 (In chinese).

Zhang, X., She, D., Wang, G., Huang, X., 2020. Source identification of soil elements and risk assessment of trace elements under different land uses on the Loess. Environ. Geochem. Health. https://doi.org/10.1007/s10653-020-00624-0

Zhao, A., Zhang, A., Lu, C., Wang, D., Wang, H., Liu, H., 2017. Spatiotemporal variation of vegetation coverage before and after implementation of Grain for Green Program in Loess Plateau, China. Ecol. Eng. 104, 13-22. https://doi.org/10.1016/j.ecoleng.2017.03.013

Zhao, G., Kondolf, G.M., Mu, X., Han, M., He, Z., Rubin, Z., Wang, F., Gao, P., Sun, W., 2017. Sediment yield reduction associated with land use changes and check dams in a catchment of the Loess Plateau, China. Catena 148, 126-137. https://doi.org/10.1016/j.catena.2016.05.010

Zhao, G., Mu, X., Jiao, J., An, Z., Klik, A., Wang, F., Jiao, F., Yue, X., Gao, P., Sun, W., 2016. Evidence and Causes of Spatiotemporal Changes in Runoff and Sediment Yield on the Chinese Loess Plateau. L. Degrad. Dev. 28(2), 579-590. https://doi.org/10.1002/ldr.2534

Zhao, Q., Wang, L., Liu, H., Zhang, Q., 2019. Runoff and sediment variation and attribution over 60 years 
in typical Loess Plateau basins. J. Soils Sediments 19(10), 3631-3647. https://doi.org/10.1007/s11368-01902345-z

Zhou, M., Deng, J., Lin, Y., Belete, M., Wang, K., Comber, A., Huang, L., Gan, M., 2019. Identifying the effects of land use change on sediment export: Integrating sediment source and sediment delivery in the Qiantang River Basin, China. Sci. Total Environ. 686, 38-49. https://doi.org/10.1016/j.scitotenv.2019.05.336

Zuo, D., Xu, Z., Yao, W., Jin, S., Xiao, P., Ran, D., 2016. Assessing the effects of changes in land use and climate on runoff and sediment yields from a watershed in the Loess Plateau of China. Sci. Total Environ. 544, 238-250. https://doi.org/10.1016/j.scitotenv.2015.11.060

Table 1 Land use types and changes in the Kuye River watershed

\begin{tabular}{lllllllll}
\hline Land use types & 1987 & 1987 & 2006 & 2006 & 2016 & 2016 & Changes (1987-2006) & Changes (1987-2006 \\
\hline & $\mathrm{km}^{2}$ & $\%$ & $\mathrm{~km}^{2}$ & $\%$ & $\mathrm{~km}^{2}$ & $\%$ & $\mathrm{~km}^{2}$ & $\%$ \\
Water bodies & 34.43 & 0.40 & 68.11 & 0.79 & 75.11 & 0.87 & 33.68 & 0.39 \\
Grass land & 2785.51 & 32.20 & 3341.47 & 38.62 & 3789.98 & 43.81 & 555.95 & 6.43 \\
Forests & 1114.21 & 12.88 & 1935.77 & 22.38 & 1981.14 & 22.90 & 821.57 & 9.50 \\
Arable land & 2182.62 & 25.23 & 1065.12 & 12.31 & 533.71 & 6.17 & -1117.50 & -12.92 \\
Shrub land & 1362.96 & 15.75 & 1524.27 & 17.62 & 1769.43 & 20.45 & 161.31 & 1.86 \\
Urban and mining area & 9.62 & 0.11 & 403.45 & 4.66 & 437.23 & 5.05 & 393.83 & 4.55 \\
Bare land & 1161.98 & 13.43 & 313.13 & 3.62 & 64.74 & 0.75 & -848.85 & -9.81 \\
\hline
\end{tabular}

Table 2 Classification of soil erosion and sediment yield

\begin{tabular}{llllll}
\hline Soil erosion grade & Soil erosion grade & Micro & Mild & Moderate & Intensi \\
\hline \multirow{2}{1}{1987} & area $/ \mathrm{km}^{2}$ & 2562.21 & 1000.08 & 1110.72 & 833.94 \\
& percentage $/ \%$ & $29.61 \%$ & $11.56 \%$ & $12.83 \%$ & $9.64 \%$ \\
2006 & area $/ \mathrm{km}^{2}$ & 4930.45 & 1002.94 & 829.68 & 509.81 \\
& percentage $/ \%$ & $57.07 \%$ & $11.61 \%$ & $9.60 \%$ & $5.90 \%$ \\
2016 & area $/ \mathrm{km}^{2}$ & 5156.11 & 982.80 & 760.44 & 470.24 \\
& percentage/\% & $59.68 \%$ & $11.38 \%$ & $8.80 \%$ & $5.44 \%$ \\
Sediment yield grade & Sediment yield grade & Low $(0-10 \mathrm{t} / \mathrm{ha} / \mathrm{a})$ & Low $(0-10 \mathrm{t} / \mathrm{ha} / \mathrm{a})$ & Moderate $(10-50 \mathrm{t} / \mathrm{ha} / \mathrm{a})$ & Moder \\
1987 & area $/ \mathrm{km}^{2}$ & 4957.94 & 4957.94 & 2030.94 & 2030.9 \\
\multirow{2}{*}{2006} & percentage/\% & $57.29 \%$ & $57.29 \%$ & $23.47 \%$ & $23.47 \%$ \\
\multirow{2}{*}{2016} & area $/ \mathrm{km}^{2}$ & 7001.38 & 7001.38 & 1097.54 & 1097.5 \\
& percentage/\% & $81.05 \%$ & $81.05 \%$ & $12.72 \%$ & $12.72 \%$ \\
& area $/ \mathrm{km}^{2}$ & 7276.03 & 7276.03 & 962.65 & 962.65 \\
& percentage/\% & $84.23 \%$ & $84.23 \%$ & $11.15 \%$ & $11.15 \%$ \\
\hline
\end{tabular}

Chinese soil erosion classification and grading standards (SL190-2007): water erosion (a) micro $(<2,<5,<$ $10 \mathrm{t} /$ ha/year), (b) mild (10-25 t/ha/year), (c) moderate (25-50 t/ha/year), (d) intensive (50-80 t/ha/year), (e) extremely intensive (80-150 t/ha/year), and (f) severe (>150 t/ha/year)

Table 3 Contribution rate of soil erosion and sediment yield reduction and average value of SDR in the Kuye River watershed

\begin{tabular}{lllll}
\hline & check dams & Land use scenarios & Land use scenarios & Land use scenarios \\
\hline & & 1987 & 2006 & 2016 \\
Average soil erosion (t/ha/yr) & Without & 116.27 & 96.88 & 86.78
\end{tabular}




\begin{tabular}{lllll}
\hline & check dams & Land use scenarios & Land use scenarios & Land use scenarios \\
\hline \multirow{2}{*}{ Decreased soil erosion } & With & 57.50 & 49.52 & 46.43 \\
& Without & & $16.68 \%$ & $25.37 \%$ \\
Average sediment yield (t/ha/yr) & With & $50.55 \%$ & $57.41 \%$ & $60.07 \%$ \\
& Without & 37.88 & 26.39 & 18.51 \\
Decreased sediment yield & With & 18.77 & 13.03 & 9.88 \\
& Without & & $30.33 \%$ & $51.14 \%$ \\
SDR & With & $50.44 \%$ & $65.61 \%$ & $73.91 \%$ \\
\hline
\end{tabular}

Table 4 Studies on the influence of check dams and land use changes on sediment yield

\begin{tabular}{llll}
\hline Reference & Watershed area $\left(\mathrm{km}^{2}\right)$ & Location & Method \\
\hline Boix-Fayos et al., 2008 & 47.2 & Rogativa catchment in Spain & WaTEM/s \\
Ran et al., 2008 & 8651 & Kuye River basin in China & Data colle \\
& 4161 & Sanchuan River basin in China & Data colle \\
Xu et al., 2013 & 7725 & Yanhe Watershed in China & SWAT mo \\
Polyakov et al., 2014 & $0.04 / 0.031$ & Santa Rita Experimental Range in the United States & Field sam \\
Zema et al., 2014 & 17.43 & Fiumara Sant'Agata in Italy & Field sam \\
Zuo et al., 2016 & 3246 & Huangfuchuan Watershed in China & SWAT mo \\
Quiñonero-Rubio et al., 2016 & 320 & Upper Taibilla catchment in Spain & WaTEM/s \\
Fortugno et al., 2017 & 26.1 & Fiumara Sant'Agata in Italy & Field surv \\
Zhao et al., 2017 & 3246 & Huangfuchuan Watershed in China & SEDD mo \\
Li et al., 2017 & 3246 & Huangfuchuan Watershed in China & SWAT mo \\
Fang, 2017 & 915 & Shuangyang catchment in China & WaTEM/s \\
Borja et al., 2018 & $0.002-0.047$ & Loreto catchment in the Andean mountains & Field surv \\
Romano et al., 2018 & 506 & Carapelle watershed in Italy & AnnAGN \\
Shi et al., 2019 & 30261 & Wuding River Watershed in China & SWAT mo \\
Guo et al., 2019 & 369 & Yanwachuan watershed in China & SEDD mo \\
Zhou et al., 2019 & 42700 & Qiantang River Basin in China & InVEST n \\
Sushanth and Bhardwaj, 2019 & 51.4 & Patiala-Ki-Rao watershed in India & WEPP m \\
Aneseyee et al., 2020 & 1091.8 & Winike watershed in Ethiopia & InVEST n \\
Choukri et al., 2020 & 180 & Tleta watershed in Morocco & SWAT mo \\
Sun et al., 2020 & 774 & Zhou River Basin in China & SWAT mo \\
\hline
\end{tabular}




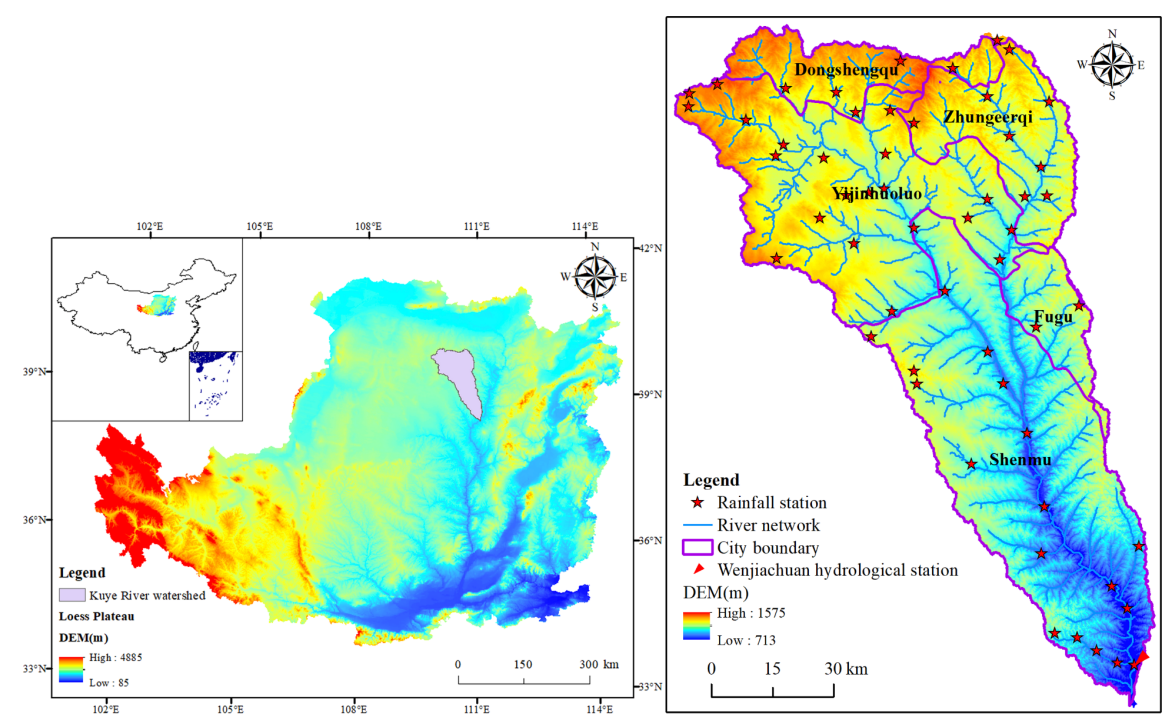

Fig. 1. Location of the Kuye River watershed. 


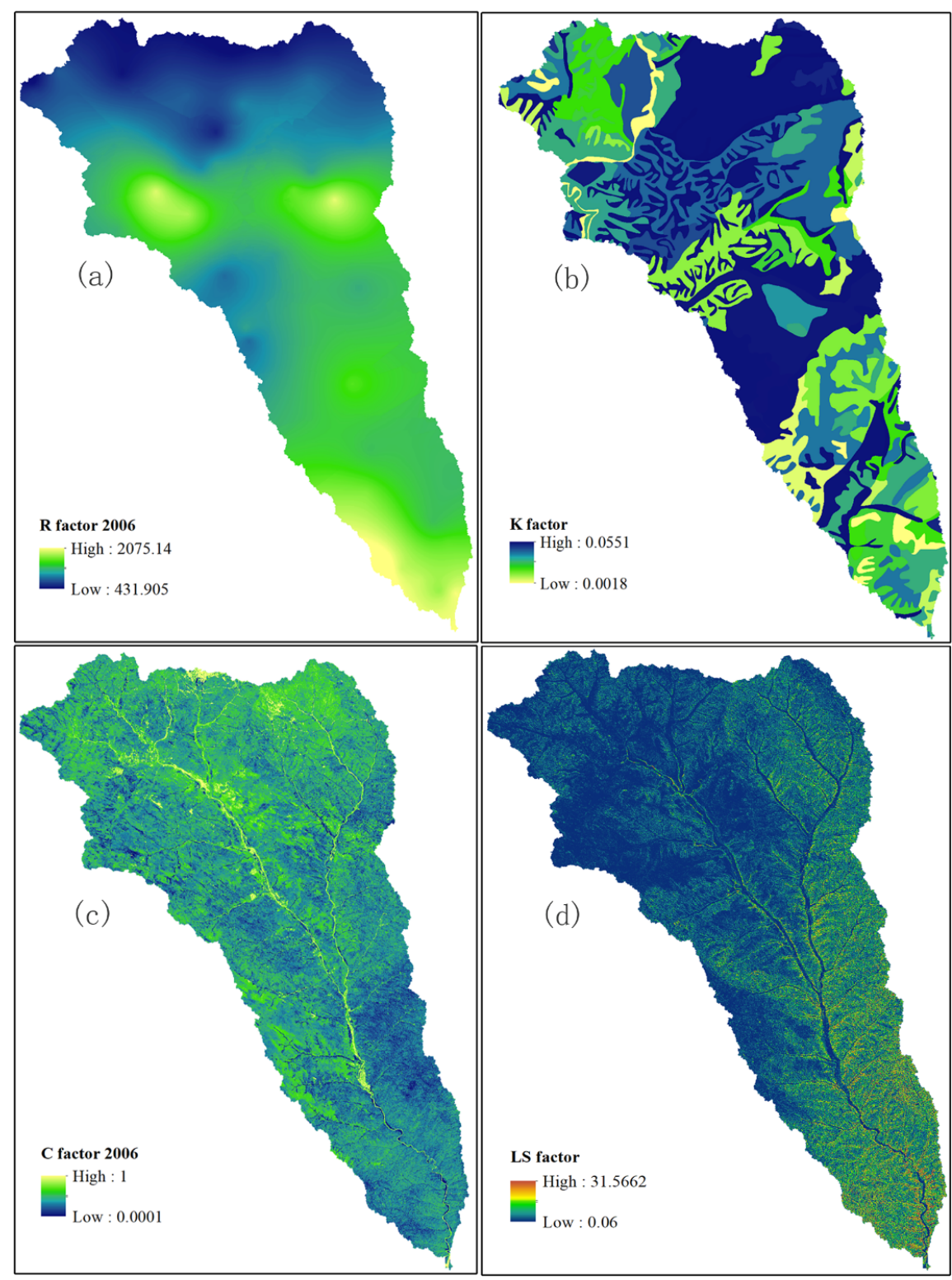

Fig. 2. Model factors of the Kuye River watershed. 


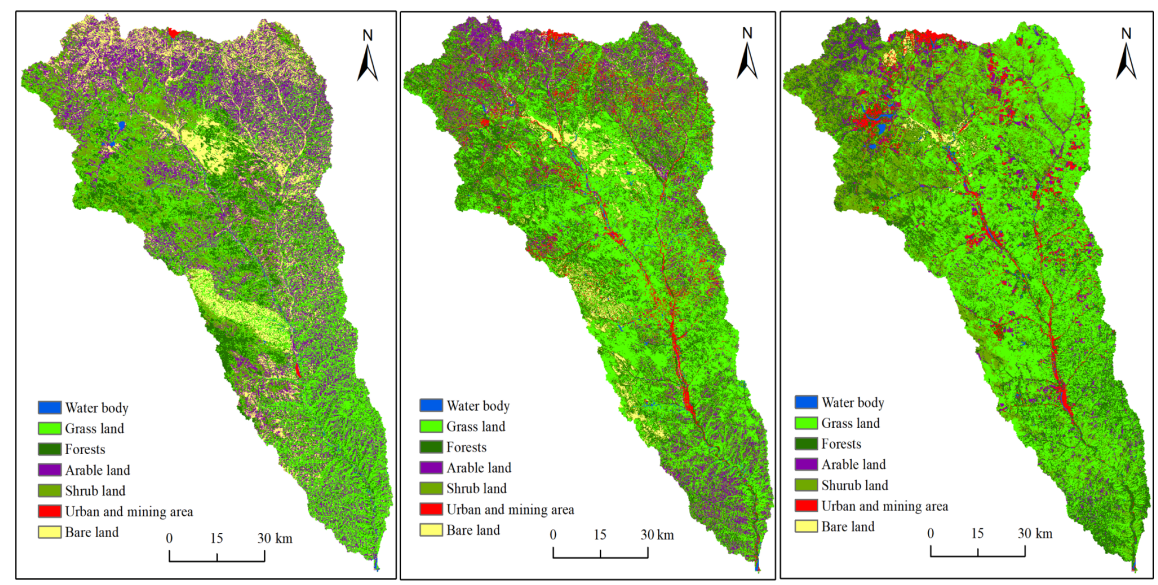

Fig. 3. Land use changes in the Kuye River watershed.

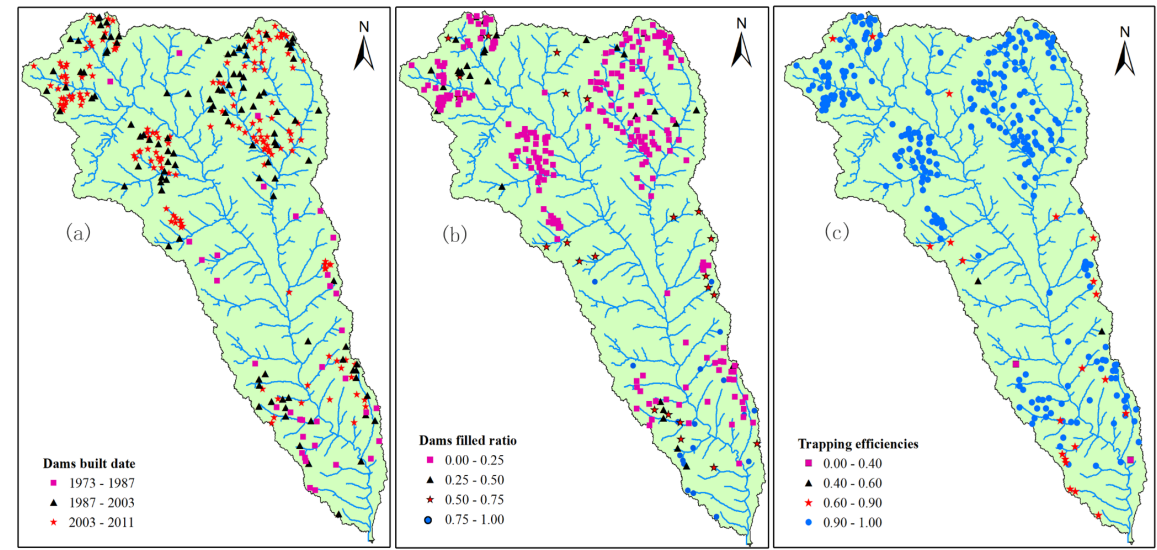

Fig. 4. Location of the check dams in the Kuye River watershed, a) division of dam construction period, b)filled dam ratio (filled storage vs total storage), c)and trapping efficiencies of dams

Fig. 5. Comparison of the measured and simulated values a) soil erosion estimation through check dam siltation and RUSLE modeling and b) sediment load simulation at the Wenjiachuan gauge. 

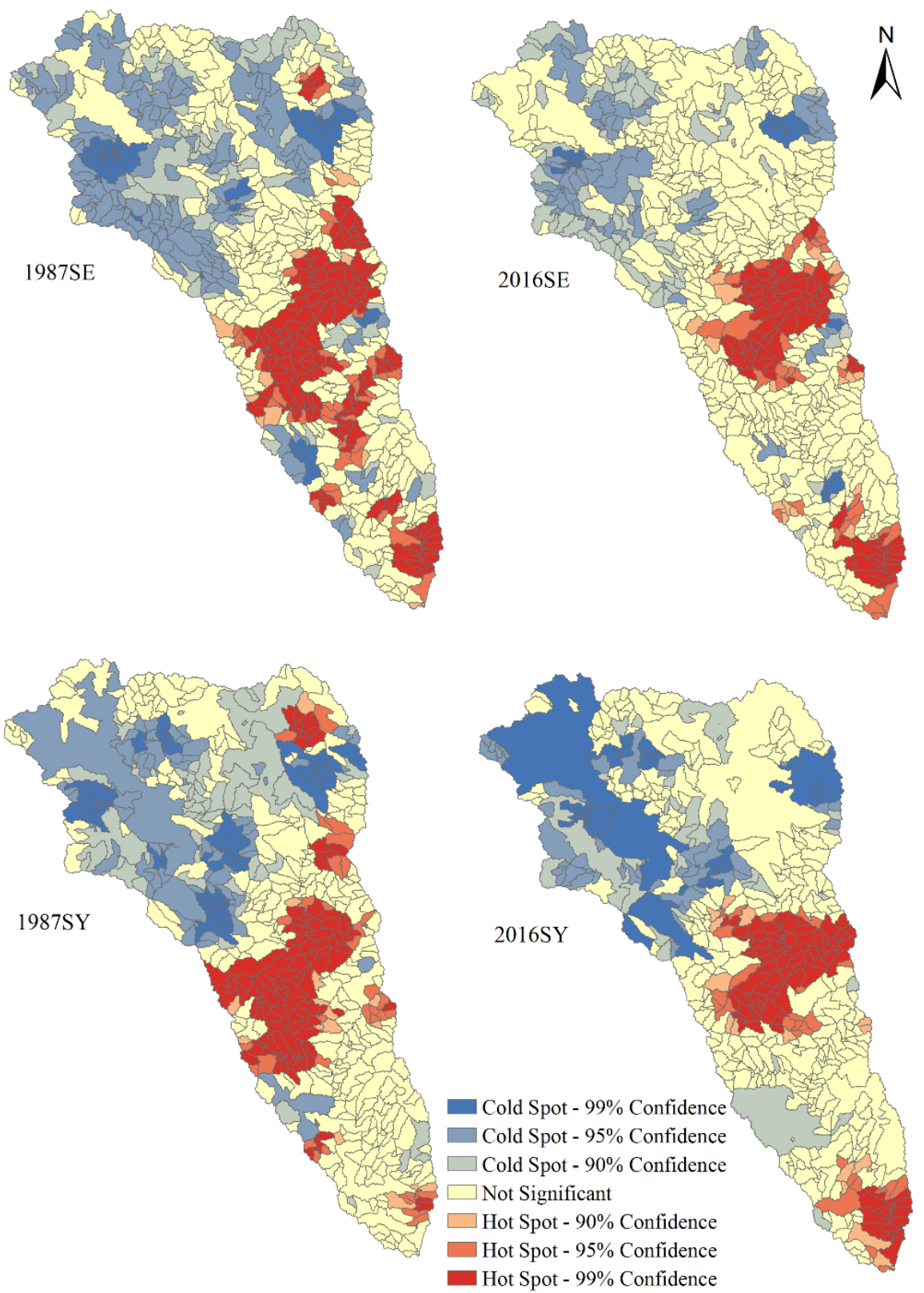

Fig. 6. Spatial distribution of hot spots and cold spots of soil erosion and sediment yield in 1987 and 2016.

Fig. 7. Total values of soil erosion and sediment yield for different land use types from 1987-2016 under six scenarios 